\title{
Organic Mulches Increase Growth of Young Pecan Trees
}

\author{
W.G. Foshee, W.D. Goff, K.M. Tilt, and J.D. Williams \\ Department of Horticulture and Alabama Agricultural Experiment Station, \\ Auburn University, AL 36849
}

\section{J.S. Bannon and J.B. Witt \\ Alabama Agricultural Experiment Station, Auburn University, AL 36849}

\section{Additional index words. Carya illinoensis, Carya illinoinensis, weed competition, yard waste}

\begin{abstract}
Organic mulches (leaves, pine nuggets, pine straw, grass clippings, and chipped limbs) were applied at depths of 10,20 , or $30 \mathrm{~cm}$ in a $3 \times 3-\mathrm{m}$ area around young pecan [Carya illinoinensis (Wangenh.) K. Koch] trees. These treatments were compared to an unmulched herbicide treatment and a common bermudagrass [Cynodon dactylon (L.) Pers.] sod. Trunk cross-sectional areas (TCSAs) of the mulched trees were larger than those of trees in the sod or unmulched plots and increased linearly as mulch depth increased. All mulches influenced TCSA similarly. Mean TCSA for mulched trees increased 14-fold compared to an increase of 8-fold for the unmulched trees and the sod in this 3-year study. Thus, common yard-waste mulches can be used effectively to increase growth of young pecan trees.
\end{abstract}

Benefits from mulching trees include cover and protection for plants from extreme temperature fluctuations (Harris, 1983), moisture conservation, evaporation reduction (Russel, 1939), increased soil organic matter, and a plant nutrient source (Ashworth and Harrison, 1983). In addition, mulching greatly reduces soil erosion. Borst and Woodburn (1942) showed that the impact of a raindrop was the main factor in causing erosion. This impact is almost eliminated when young trees are mulched (Harris, 1983). Mulching also greatly reduces the number of weeds and, therefore, their competitive effects (Autio et al., 1991; Harris, 1983).

Effects of mulching on young pecan trees are not well documented. One of the few studies found that a bark mulch was effective in controlling weeds in plantings of young pecans (Hershey, 1976). Mulching young pecan trees would be expected to provide benefits similar to those provided other trees. The purpose of this study was to determine the effects of growing young pecan trees with various organic mulches and to determine the depth of mulch that was most advantageous.

\section{Materials and Methods}

Container-grown 'Desirable' pecan trees were planted in Oct. 1991 on a $9.1 \times 10.7-\mathrm{m}$ spacing at the E.V. Smith Research Center, located in central Alabama. The experiment was a randomized complete block design with

Received for publication 16 Nov. 1995. Accepted for publication 26 Mar. 1996. Alabama Agricultural Experiment Station Journal Series no. 11-955091. We thank the Tennessee Valley Authority for funding this project, and Laura G. Sanders for assisting with statistical analyses. The cost of publishing this paper was defrayed in part by the payment of page charges. Under postal regulations, this paper therefore must be hereby marked advertisement solely to indicate this fact. four single-tree replications. Each of these contained five mulch types (hardwood leaves, pine nuggets, pine straw, grass clippings, and chipped limbs) with four mulch depths $(0,10$, 20 , and $30 \mathrm{~cm})$, plus a plot of common bermudagrass sod (sod) laid around trees at the time of the initial mulch application, and a plot without mulch, but herbicide-treated $(\mathrm{H})$. All treatments were maintained in a $3 \times 3-\mathrm{m}$ area centered on the trees.

Mulches were applied initially in Feb. 1992 and replenished annually in 1993 and 1994 during dormancy to maintain the specified depth. Trees in the $\mathrm{H}$ plots received a preemergence application of 4-(dipropylamino)-3,5dinitrobenzenesulfonamide (oryzalin) plus 4ch 1 oro-5 - ( met hy la mino ) - 2 - [ 3 (trifluoromethyl)phenyl]-3(2H)-pyridazinone (norflurazon) plus [ $\mathrm{N}$-(phosphonomethyl)glycine] (glyphosate) at 2.2, 2.8, and $1.7 \mathrm{~kg}$ a.i./ ha, respectively, in Mar. 1992, 1993, and 1994. Trees were fertilized uniformly based on leaf and soil samples (O'Barr et al., 1989) taken from all treatments and averaged. Trees were not irrigated and were maintained according to standard recommendations (Worley, 1989).

Trunk circumference was measured at a marked location on the trees $40 \mathrm{~cm}$ above ground level on 9 Mar. 1992 and 4 Apr. 1995, and was then converted to trunk cross-sectional areas (TCSAs). Data were analyzed with SAS's GLM procedure (SAS Institute, 1990) and with single-degree-of-freedom contrasts, which were used to compare selected treatment groupings. Least significant difference (LSD) was used for comparison of all treatments.

\section{Results and Discussion}

After 3 years, the TCSAs of trees where mulches were applied $(10,20$, or $30 \mathrm{~cm})$ were in $\mathrm{H}$ plots. The mean TCSA for the mulched larger than those of trees grown with the sod or trees was $43.4 \mathrm{~cm}^{2}, 27.2 \mathrm{~cm}^{2}$ for $\mathrm{H}$, and 25.4 $\mathrm{cm}^{2}$ for the sod. Mean TCSA for mulched trees had increased 14.0-fold after 37 months of growth but only $\approx 8.0$-fold for $\mathrm{H}$ and sod.

TCSA did not differ for mulch material (Table 1). When the data for mulch type and depth were analyzed as a factorial, there was no mulch $\times$ depth interaction, suggesting that response to mulch depth was similar regardless of mulch type. Therefore, the data for mulches were pooled, and regression analysis was used to determine effect of mulch depth. TCSA increased linearly as mulch depth increased $(P \leq 0.001)$ (Fig. 1).

In this study, young pecan trees grown with any mulch grew more than those grown with sod or unmulched. Our data indicate a $60 \%$ to $70 \%$ growth increase from mulch compared to $\mathrm{H}$ and sod, respectively. In pecans, early growth correlates positively with early production (Patterson and Goff, 1994); and a growth improvement of $151 \%$ was associated with a 5-fold yield increase through the first 7 years from young 'Desirable' trees. If mulches can be obtained free, which may be possible because some mulches are considered yard waste, a grower may only have to pay for spreading the material. Our results indicate that an application soon after planting of at least $20 \mathrm{~cm}$ of organic mulch would improve tree growth substantially. In a commercial pecan orchard, trees produce a harvestable crop in 5 to 7 years after planting. At this time, mulches would be undesirable because they would interfere with harvesting. However, a mulch applied at planting likely would be decomposed after 5 years and, therefore, would not interfere with the harvesting operation. Thus, mulching young pecan trees during the first few years appears to be beneficial.

Table 1. Effects of yard-waste mulch on trunk crosssectional area (TCSA) of young pecan trees after three growing seasons. ${ }^{\mathrm{z}}$

\begin{tabular}{lc}
\hline \hline Mulch & TCSA $\left(\mathrm{cm}^{2}\right)$ \\
\hline Type & 48 \\
Leaves & 46 \\
Pine nuggets & 43 \\
Pine straw & 42 \\
Grass clippings & 39 \\
Chipped limbs & 27 \\
Unmulched, herbicide treated & 25 \\
Sod & \\
Depth ${ }^{y}(\mathrm{~cm})$ & 31 \\
$0^{\mathrm{x}}$ & 39 \\
10 & 46 \\
20 & 45 \\
30 & \\
Significance $(P>$ F) & \\
Mulch type & 0.2709 \\
Mulch depth & 0.0031 \\
Mulch $x$ depth & 0.7133 \\
Contrasts $(P>$ F) & \\
Depth linear & 0.0005 \\
Depth quadratic & 0.1227 \\
Mulch vs. sod & 0.0008 \\
Mulch vs. unmulched & 0.0018 \\
\hline
\end{tabular}

${ }^{\mathrm{z}}$ Mulch values are means of 12 trees grown at three mulch depths $(10,20$, and $30 \mathrm{~cm})$, unmulched and sod values are means of 12 trees each.

${ }^{y}$ Mulch depth values are means of 20 trees.

'Values are means of 80 trees grown at four mulch depths $(0,10,20$, and $30 \mathrm{~cm})$. 


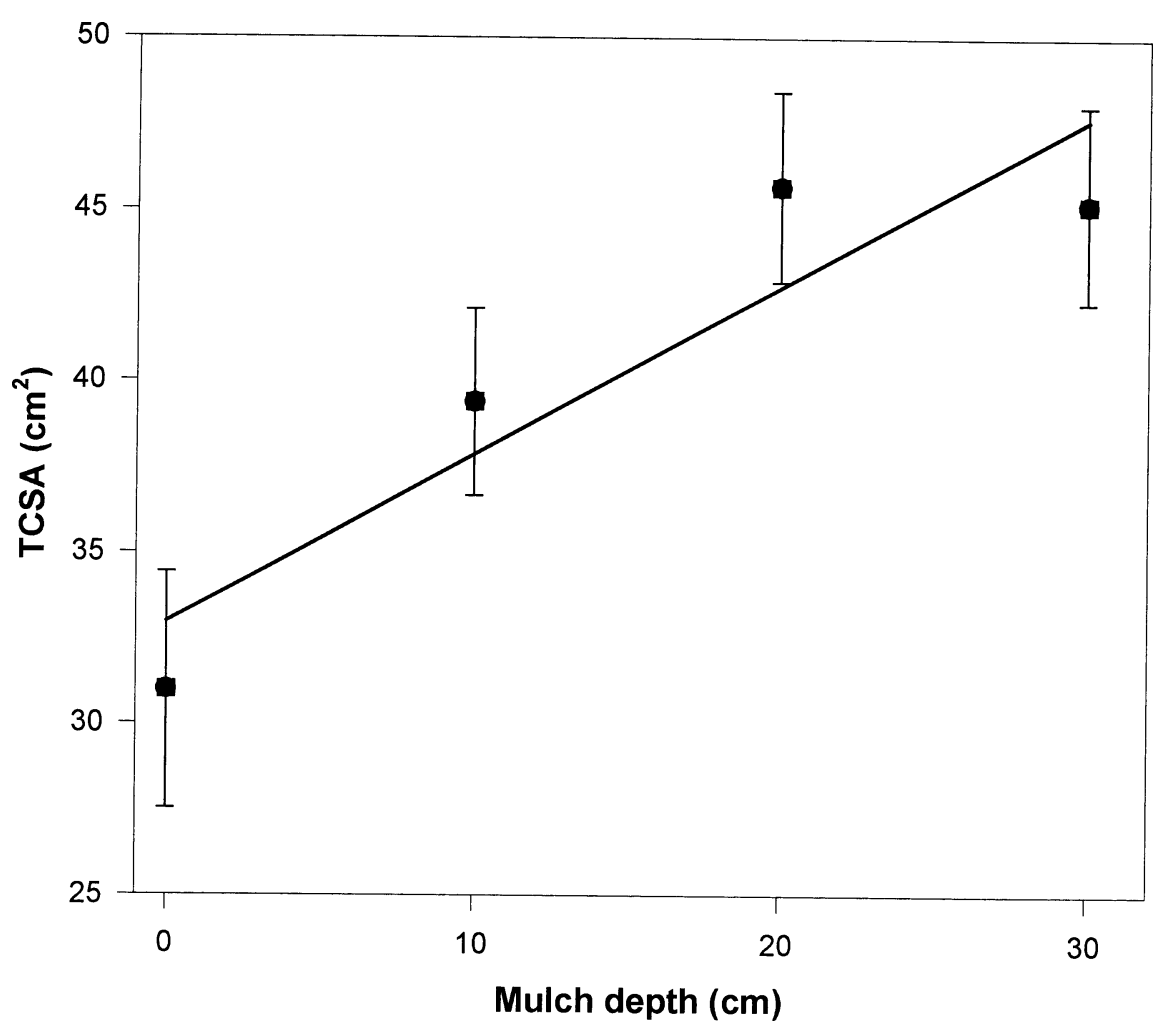

Fig. 1. Effect of depth of organic mulches on trunk cross-sectional area (TCSA) of young pecan trees Four data points represent mean for all mulches: leaves, pine nuggets, pine straw, grass clippings, and chipped limbs. Zero depth treatment was unmulched and herbicide-treated. Regression equation was $\mathrm{y}=33.2+1.2(\mathrm{D}), \mathrm{r}^{2}=0.15, P=0.0006, \mathrm{n}=75$. Each point is mean of 20 trees plus standard errors (indicated by vertical bars).

\section{Literature Cited}

Ashworth, S. and H. Harrison. 1983. Evaluation of mulches for use in the home garden. HortScience 18:180-182.

Autio, W.R., D.W. Greene, D.R. Cooley, and J.R. Schupp. 1991. Improving the growth of newly planted apple trees. HortScience 26:840-843.

Borst, H.L. and R. Woodburn. 1942. The effect of mulching and methods of cultivation on runoff and erosion from muskingham silt loam. Agr. Engineering 23:19-22.

Harris, R.W. 1983. Arboriculture: Care of trees, shrubs, and vines in the landscape. PrenticeHall, Englewood Cliffs, N.J.

Hershey, F. 1976. Evaluation of typar as a potential tree mulch. Northern Nut Growers Assn. Annu. Rpt. 76:165-169.

O'Barr, R.D., M. Smith, G. Taylor, and W.D. Goff. 1989. Pecan nutrition, p. 61-72. In: W.D. Goff, J.R. McVay, and W.S. Gazaway (eds.). Pecan production in the southeast...A guide for growers. Alabama Coop. Ext. Serv., Auburn Univ.

Patterson M.G. and W.D. Goff. 1994. Effects of weed control practices and irrigation on the growth of young pecans. Weed Technol. 4:892894.

Russel, J.C. 1939. The effects of surface cover on soil moisture losses by evaporation. Proc. Soil Sci. Soc. Amer. 4:65-70.

SAS Institute. 1990. SAS/STAT user's guide, version 6, 4th ed., vol. 2. SAS Inst., Cary, N.C.

Worley, R. 1989. Establishing an orchard, p. 52-53, 56-58. In: W.D. Goff, J.R. McVay, and W.S. Gazaway (eds.). Pecan production in the southeast...A guide for growers. Alabama Coop. Ext. Serv., Auburn Univ. 